\title{
ONLINE EDUCATION: CHALLENGES AND PROSPECTS
}

\section{Larysa Oleksiienko ${ }^{1}$, Liubov Sheptytska ${ }^{2}$, Olena Fonariuk ${ }^{3}$}

${ }^{1}$ Ph.D. (Pedagogy), Associate Professor, Department of Social Work and Language Training, Affiliate "Kremenchuk Institute of Higher Educational Establishment "Alfred Nobel University",Kremenchuk, Ukraine, e-mail: oleksienko@mail.ru, ORCID: https://orcid.org/0000-0002-3509-388X

${ }^{2}$ Ph.D. (History), Associate Professor, Acting Head of the Department of History of Ukraine, Economic Theory and Law, National Forestry University of Ukraine, Lviv, Ukraine, e-mail: shlubov@ukr.net, ORCID: https://orcid.org/0000-0003-3070-0131

${ }^{3}$ Ph.D. (Pedagogy), Associate Professor, Department of Algebra and Geometry, Faculty of Physics and Mathematics, Zhytomyr Ivan Franko State University, Zhytomyr, Ukraine, e-mail: f-ev@i.ua, ORCID: https://orcid.org/0000-0001-7879-5884

Abstract. Today, online education is a modern and effective tool for increasing the competitiveness of universities, meeting the various needs and interests of consumers of educational services, and implementing the concept of continuing education. This determines the relevance of studying and describing trends and prospects for the development of online education in Ukraine. The aim of the article is to study the features of online education in Ukraine, its problems and perspective directions of development. Methods: Logical method was used in order to understand the meaning of online education; methods of system analysis were used to identify trends that accompany the development of online education in Ukraine; comparative analysis - made it possible to compare the phenomena in order to establish similarities or differences between them. Results: The article highlights the directions of the penetration of Internet technologies into the educational process. The essence of the concept of "online education" is revealed. The model of online education by T. Anderson is considered and the author's interpretation of online education is provided. It is noted that not only students, but also young people who do not have the opportunity to simultaneously combine study with work or who live in areas remote from the regional centers, can get an online education; housewives; military personnel; managers are ready to get a second education. The trends that accompany the development of online education in Ukraine have been identified. Problems of the introduction of online education have been formed (insufficient professional training of teachers and teachers; reluctance of students; limited implementation of information technologies in educational institutions, lack of a single educational standard for online learning, lack of a favorable environment). Promising directions for further development of online education in order to improve its quality were identified. Therefore, there is an intensive development of online education, both throughout the world and in Ukraine. Online courses contain significant pedagogical potential associated with informatization and intensification of the educational process. Online courses in the near future will form a real foundation for continuing learning.

Keywords: Internet technologies; online learning; online courses; student; teache; online educational environment.

JEL Classification: I0; I20

Formulas: 0; fig.: 0; tabl.: 0; bibl.: 15

Introduction. The education system in the 21 st century is directly related to information technologies, which are rapidly developing. Their dissemination requires the educational system to adapt to the new reality, resolve urgent issues, develop new methods and forms of education. Therefore, over the past twenty years, it has increasingly become the subject of research on the use of online education and the inclusion in the educational process of its individual elements, such as electronic or online courses. 
Today, online education is a modern and effective tool for increasing the competitiveness of universities, meeting the various needs and interests of consumers of educational services, and implementing the concept of continuing education. Ukraine, as a state with a developed education system, is also actively involved in this process. This determines the relevance of studying and describing trends and prospects for the development of online education.

Literature Review. The work of such scientists is devoted to the implementation of online education - conducting webinars, courses, online meetings, Internet conferences: T Anderson, T. Vorobieva, M. Horn, S. Danver, O. Dereza, E. Kirsanova, V. Kryzhanivska, Y. Opanasyuk, A. Khalikov. The problems of online education were investigated by: I. Deinega, D. Mamatov, Yu. Navolochnaya. The theoretical and practical foundations for creating open online courses in Ukraine have been developed by: V. Bykov, V. Oliinyk, V. Osetskyi, I. Tatomyr.

Highlighting previously unsolved parts of the general problem to which this article is devoted. In Ukraine, at present, quite a lot of attention is paid to the development of the educational system, while there is not enough research devoted directly to online education.

Aims. The aim of the article is to study the features of online education in Ukraine, its problems and perspective directions of development.

Methods: Logical method was used in order to understand the meaning of online education; methods of system analysis were used to identify trends that accompany the development of online education in Ukraine; comparative analysis made it possible to compare the phenomena in order to establish similarities or differences between them.

Results: The development of electronic culture, informatization, globalization and technological openness has even touched those areas that have not changed for centuries, for example, the education system. It should be noted that the penetration of Internet technologies into the educational environment in Ukraine occurs in the following directions.

Firstly, it is an increase in the efficiency of the work of budgetary educational institutions. Such implementation consists both in optimizing existing processes (online schedule, using digital technologies in lectures, etc.) and in creating new ones (distance learning using online courses). Information technology in this area mainly improves the operation of the existing system, since changes in regulations are not on track to technological progress.

Secondly, the emergence of many paid online courses and educational services offered by the business sector. This segment of the online education market is its most flexible and advanced component, since the competition here is moving towards perfect. Along with large world-scale companies, there are many representatives of medium, small and micro-businesses specializing in narrow niches in this market. The specificity of the latter's activities is the almost complete absence of regulation by the state and professional communities and, in many cases, the shadow nature of their activities. If the work and income of more or less large organizations that are in the center of attention in their fields of activity can be monitored, then educational 
services offered by bloggers, freelancers, financial advisers, tutors and other Internet users cannot be tracked. The channels for obtaining such services are usually social networks.

Thirdly, these are Internet resources that provide educational information and educational services free of charge. From a global perspective, the online encyclopedia (Wikipedia), thematic forums, blogs and blog platforms (for example, Habrahabr) is an important source of knowledge for those engaged in self-education. In addition, free educational materials in applied areas of knowledge (coding, sewing, working with plumbing, etc.) are offered in social networks such as Instagram and Youtube.

As noted A. Dereza, R. Sklyar and S. Dereza, new Internet technologies provide new opportunities. A few years ago, to obtain Western business knowledge, we traveled abroad, today you can listen to business courses of teachers online for free. You need to pay for the course only if you want to get a diploma. So, just sitting in the Ukrainian office, you can communicate "sincerely" in English with foreign professors. All this is due to the rapid development of webconferencing in our time (Dereza, Sklyar \& Dereza, 2020).

The indicated development of information technologies has made the problem of modernizing the education system of Ukraine urgent. Online education is a shining example of such modernization, which, thanks to the Internet, covers wide sectors of society and becomes an important factor in its development.

The theoretical interest in online education first arose in the context of studying the experience of distance education, the desire to understand its capabilities in connection with the use of new information and communication technologies (ICT) in the educational process. V. Kirsanov and V. Chernenko consider distance learning in the information society as a process in which "purposeful mediated interaction between a student and a teacher is carried out on the basis of information technologies, primarily using telecommunications and television" (Kirsanova \& Chernenko, 2012).

The adoption of the new law "On Education" initiated the interest of researchers in another concept that is widely used to characterize online education - "e-learning". It became the subject of cognitive interest in the works of D.N. Mamatova (Mamatov, 2015), Yu. Navolochnaya (Navolochnaya, 2014), T.A. Vorobieva (2014) and others. Generally, researchers do not distinguish between distance and e-learning. Moreover, the study of the prevailing discursive practices of using the term "online education" shows that there are no differences between it, e-learning and distance learning. The consequence of this arbitrary interpretation of the concepts is that, when characterizing online learning, specialists determine at least three forms of its application in the educational system: 1) synchronous (in a single time mode) interaction of a teacher and a student using telecommunication technologies; 2) collective viewing in the audience of video lectures recorded by teachers from other universities; 3) asynchronous - self-education using electronic information packages created by specialists for a specific training course (massive open online courses). 
According to the scientist A.A. Khalikov, one of the prospects for the development of online learning in an educational institution can be called asynchrony, the student receives, accumulates knowledge in a certain area, and the teacher and the educational institution control and refer them in the right direction. The student mainly interacts with his tutor (Khalikov 2013).

In this article, we rely on the most consistent, in our opinion, concept of online learning proposed by T. Anderson (Anderson, 2011). It provides that the entire educational process is exclusively in online format and the result fully or almost completely corresponds to the results of full-time education (Danver, 2016). The most frequently, online learning is carried out using a specific platform on which information is learned, and the format of this process resembles, but does not necessarily repeat, interaction in the classroom (Horn \& Staker, 2014). An indisputable advantage of Anderson's concept is the online learning model (Fig. 1), which includes all participants in the online learning process and its key elements: teacher, student and knowledge. This approach allows you to determine the relationship between various elements, and typologies of online learning forms do not require strict categorization, since each form can represent a unique set of characteristics.

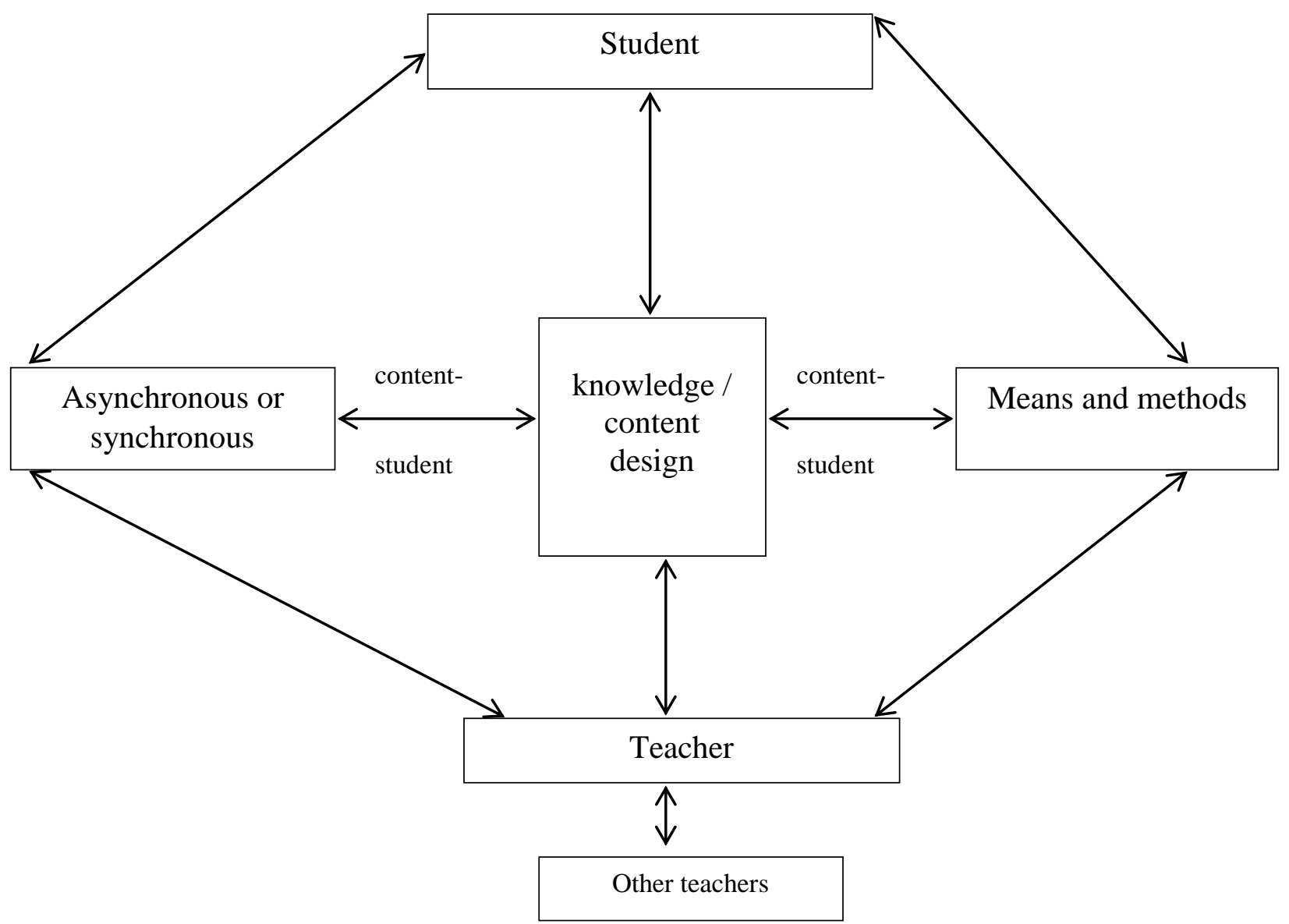

Figure 1. T. Anderson's online learning model

Source: Compiled by the author based on (Anderson, 2011)

The conducted analysis allows filling the content volume of online education as an asynchronous or synchronous interaction between a teacher and a student and 
defining it. We distinguish three features: 1) the interaction between the teacher and the student is carried out in real time; 2) the interaction between the teacher and the student takes place using ICT resources; 3 ) the interaction between the teacher and the student takes place in a remote format. Since online education incorporates features inherent in various forms of education, and they are of equal importance for its characteristics, this leads us to the idea of the need to separate online education into a separate, fundamentally new, next to distance and classroom-contact education, form of the educational process, which takes place in a remote mode of one-time interaction between a teacher and a student, which is provided through the use of information and telecommunication networks. This is a fundamentally new educational form, which has long been used on the Internet for any kind of forums and commercial trainings, but has not yet been practically used in the system of higher professional education. And, what is especially important, it does not have legislative legitimation, since it does not cover the scope of characteristics either through e-learning or through distance educational technologies.

Researchers which study trends that accompany the development of online education in Ukraine: Deinega, 2018; Kryzhanivska, 2016; Opanasyuk, 2016; Osetsky \& Tatomir, 2017; Romanovsky, Kvasnyk, Moroz ets, 2019; Shabanov, 2018:

1 . The growing role of certification of massive online courses. This natural trend is associated with the need to control the quality of online education and the desire to ensure its comparison with formal education in different countries of the world. Among the certification tools for online courses, various ratings and expert assessments are being developed.

2. Intensive use of video materials in the content of online courses. Animations, presentations, videos in popular social networks are becoming an obligatory component of online courses, especially since the quality of mobile communications, access to the Internet and the number of smartphone users are growing every year. However, webinars are losing their power.

3. Active use of game learning. Game technologies in teaching make it possible to diversify the ways of educational interaction, provide a higher involvement in the researched subject, since the visual perception of information significantly increases the assimilation of educational material. In addition, game technologies contain opportunities for choosing individual educational strategies, assessing the ways of action and decision-making while mastering of educational material.

4. Online learning is becoming more flexible and variable, and also undertake short-term. Since the main consumer of online education is people who work and already have basic education and who want to improve their qualifications or master a new field of activity, they have significantly limited time opportunities for training. Therefore, the content of effective and demanded online courses consists of small and different in form teaching materials (video, text, presentations, etc.). It is easy to learn and allows you to implement the learning concept anytime, anywhere.

5. Using elements of virtual and augmented reality in online education. This trend has arisen due to the development of electronic technologies, since virtual reality technologies have become more accessible and have shown their effectiveness 
in the professional training of physicians, historians, etc. Due to the use of such technology, it becomes possible to fully immerse in the process under study at an emotional level, and there are opportunities to form and improve necessary skills, etc. Among the advantages of virtual reality technology is the ability to visualize objects and processes, safety of use (there is no fear of damaging the object), etc. However, this technology will most likely not be widely used in the near future due to its high price and complexities of development for the mass user.

6. Active adaptation of existing content to new requests of listeners. This trend manifests itself in content modernization and constant updating. In most areas, information and technology updates are made less frequent, but requests for training content may vary. Therefore, the winners are those companies that closely follow the changes in legislation, improve and expand on the existing materials. Therefore, online courses are increasingly acquiring the features of "road maps", which purposefully allow you to master a particular skill which means online learning becomes personalized.

7. Development of social learning and mentoring in the format of online courses. An increasing number of companies are trying to use their potential for training and development of their employees, that means corporate online training is developing. Today it exists both on social networks, internal chats and forums, and on specialized sites. In recent years, there has been a tendency to strengthen the internal requirements of companies to study such way, and the rules for certification of corporate online projects are being more strictly. Due to corporate courses, a more complete satisfaction of the requirements of companies is achieved, internal resources are saved for employee training, and feedback is provided between mentors and newcomers to companies.

However, along with all the innovations associated with the introduction of a range of new technologies into the educational space, there are a number of related problems in the development of online education (Table 1).

As you can see from the table 1, there is a number of pressing problems in the field of online education that need to be solved in order to improve its quality. The main directions for solving these problems are: creation of an adaptive educational online environment for teachers and students. In the process of adaptation, teachers must learn the basics for being able to teach, and students for being able to learn. The next direction is the preparation of educational institutions for the integration of information and communication technologies. Creation of a single educational standard for online learning: electronic textbooks, methodological recommendations, teaching aids, as well as various complexes and programs.

Innovations in pedagogy can make a significant contribution to solving these problems. For this, it is necessary to conduct new research in the field of application of information technologies in pedagogy, to study the influence of information technologies on pedagogy in general, as well as on teachers and students.

In our opinion, the most perspective direction for the development of the educational process in the electronic space is massive online open courses, which are 
a connecting link that can bring the educational process and the modern information space closer together.

\section{Table 1. Problems of the development of online education in Ukraine}

\begin{tabular}{|c|c|}
\hline Problem & Description \\
\hline $\begin{array}{l}\text { 1. Insufficient } \\
\text { training of teachers } \\
\text { and educators }\end{array}$ & $\begin{array}{l}\text { The readiness of the teacher himself is one of the main elements in online } \\
\text { learning. When integrating computer technology into online education, it } \\
\text { is imperative to ensure that teachers are prepared for such innovations. } \\
\text { Successful online learning begins with the confidence of educators that } \\
\text { they are capable of learning all technologies and applying them } \\
\text { successfully. Mass training of teachers and educators in the field of } \\
\text { information technology will contribute to the development of online } \\
\text { learning and modern pedagogy }\end{array}$ \\
\hline $\begin{array}{l}\text { 2. Unwillingness of } \\
\text { students }\end{array}$ & $\begin{array}{l}\text { During the process of online learning, students face a number of obstacles } \\
\text { in the form of their own individual characteristics, learning conditions, } \\
\text { the ability to use computer technologies and Internet resources. Today, } \\
\text { there are no online programs that take into account certain individual } \\
\text { characteristics of each student and, most likely, it is impossible to create } \\
\text { such individual programs. Therefore, it is necessary to develop an } \\
\text { educational online environment that will be aimed at adapting all students } \\
\text { to online learning. }\end{array}$ \\
\hline $\begin{array}{l}\text { 3. Limited amount } \\
\text { of implementation } \\
\text { of information } \\
\text { technologies in } \\
\text { educational } \\
\text { institutions }\end{array}$ & $\begin{array}{l}\text { This implementation requires huge resources - time and money. A wide } \\
\text { range of new curricula, guidelines, instructions, manuals, examples of } \\
\text { online lessons. Educational institutions that have decided to add online } \\
\text { learning to their range of educational services must have all the necessary } \\
\text { equipment. The opportunity for decent online learning depends on well- } \\
\text { trained educational institutions }\end{array}$ \\
\hline $\begin{array}{l}\text { 4. Lack of a single } \\
\text { educational standard } \\
\text { for online learning }\end{array}$ & $\begin{array}{l}\text { This is due to the fact that most teachers do not want to work for an } \\
\text { external educational program if it was not invented by them. Other } \\
\text { educators are reluctant to provide their own developed programs for the } \\
\text { possibility of following them legally. Also, each educational institution } \\
\text { aims to develop its own program, which, in their opinion, is the best } \\
\text { among others. The lack of a single standard, at least in the main points of } \\
\text { education, directly affects the educational process. In our opinion, the } \\
\text { only educational standard in online education will allow getting rid of } \\
\text { low-quality programs in this area. This fact will positively affect the } \\
\text { learning process. }\end{array}$ \\
\hline $\begin{array}{l}\text { 5. Lack of a } \\
\text { supportive } \\
\text { environment }\end{array}$ & $\begin{array}{l}\text { In standard learning, the atmosphere between teacher and student is often } \\
\text { intensive. The standard learning process "put student under some } \\
\text { pressure", sometimes even the teacher. Generally, most students would } \\
\text { happily skip the entire learning process to avoid stress. Teachers, in turn, } \\
\text { do not understand why to teach those who do not want it. Therefore, } \\
\text { online training should solve these problems. During online learning, } \\
\text { teachers only "give" information, and students turn it into useful } \\
\text { knowledge, use only the method of self-study. And the function of } \\
\text { monitoring progress is transferred to the computer. This should create a } \\
\text { supportive learning environment. However, as experience has shown, the } \\
\text { introduction of information technologies partially influenced the } \\
\text { consciousness of people. Most often, both sides of the educational } \\
\text { process remain conservative in their views. }\end{array}$ \\
\hline
\end{tabular}


The teacher's competent use of all the possibilities of massive online open courses will allow him to reach a new level of his professional activity and pedagogical skills, since it will require the teacher to maximize all aspects of his activity. At the same time, the teacher gets a huge scope for creativity in the process of creating his own authoring courses, when, in fact, no one and nothing limits him and he can realize all his creative ideas, ideas, presentations, presentation of material, new approaches to organizing training sessions and conducting control measures that "do not fit" into the existing framework of the educational process created by the Ukrainian education system. The teacher will be able to deviate from generally accepted educational standards and be the "creator" of their course.

However, the creation of open online courses will require from the teacher not only exceptional knowledge of the material included in the course content, but also computer skills that go beyond the usual "boundaries" of work in office programs. In addition, the work on creating online courses should be accompanied by creative approaches to the design of the material and the forms of its presentation.

It is important to note the fact that the teacher should not consider his own online course as a commercial project, since one of the basic principles of implementing massive online courses is to distribute them free of charge. An open online course should not be created for the purpose of making money, but with the aim of expanding the audience of its listeners. This will allow the teacher to attract completely different people to his course from different regions, not only in Ukraine, but also from foreign countries. An online course can also interest not only students, but also other teachers. Therefore, during developing, it will be a good idea to provide the possibility of communication between students and the author of the course, not only to answer questions from students, but also to receive feedback and recommendations on improving both the material of the educational course and the approaches to its conduct.

At the same time, successful work on the creation and promotion of open online courses will help to increase the rating and authority of the teacher in the educational environment. This will open the teacher's access to cooperation with other teachers and the creation of joint interesting educational courses and other similar projects also it will allow him to participate in such programs of massive open online training at the sites of leading organizations in this field.

In turn, the educational process in the implementation of mass online education will be able to reach a new level and will allow educational institutions to achieve the following qualitative and quantitative improvements:

- expanding the access of students to education and training;

- improving the quality of education;

- reducing in value of training;

- reducing the cost of providing the educational process;

- increasing income from educational activities by attracting more listeners;

- an increase in the number of courses taught;

- active training in programs not only basic, but also additional education, as well as advanced training and professional retraining; 
- the use of information and communication resources not only for educational purposes, but also for activities related to the educational process.

As a result, the teacher will become a part of the global "educational mechanism", will constantly develop as a professional and teacher, open up access to knowledge for a large number of students and help them become professionals.

Discussions. The emergence of massive online courses is based on the implementation of modern educational principles of openness in education, equality of participants in the educational process, internationalization of educational systems, globalization of the educational space, individualization of education. The rapid development of such courses casts doubt on the effectiveness of the traditional education system, and today massive online courses are challenging it, collecting millions of donations and participants. Supporters of online education are confident that in the near future students will be able to completely "enrich" their knowledge of online courses posted on the Internet, and the system of traditional education will be radically transformed.

Conclusions. Therefore, it can be argued that there is an intensive development of online education, both around the world and in Ukraine. Online courses contain significant pedagogical potential associated with informatization and intensification of the educational process. In our opinion, online courses in the near future will form a real basis for continuing learning.

Among the main trends in the development of online education, the application of various technologies is leading, such as video content, game programs, elements of virtual or augmented reality. But the focus remains on people who do not want to waste time learning everything about everything. The main function of training is to provide clear answers to questions and consolidate the necessary skills. The decisive factor will remain a person's motivation and his willingness to regularly devote time to self-education.

Author contributions. The authors contributed equally.

Disclosure statement. The authors do not have any conflict of interest. References

1. Vorobieva, T.A. (2014). On the concept of e-learning. Ideas and ideal, 2, 143-152.

2. Deinega, I.O. (2018). Online education in the development of the information society. Black Sea Economic Studies, 30-1, 78-82.

3. Dereza, O.O., Sklyar, R.V. \& Dereza, S.V. (2020). Online learning methods. Improving the educational process in higher education: a collection of scientific and methodological works, 82-90.

4. Kirsanova, E.V. \& Chernenko, V.I. (2012). On the question of distance education. Bulletin of the Association of Universities of Tourism and Service, 3, 79-86.

5. Kryzhanivska, V.I. (2016). Features of introduction of e-learning technologies in higher education of Ukraine. Social technologies: current issues of theory and practice, 69-70, 205-215.

6. Mamatov, D.N. (2015). E-learning in education. Lifelong learning, 13, 12-16.

7. Navolochnaya, Yu.V. (2014). Features of control in e-learning. Pedagogy and psychology of education, 4, 51-54.

8. Opanasyuk, Y. (2016). Distance learning as a consequence of the evolution of the traditional education system. Higher education in Ukraine, 1, 49-53.

9. Osetsky, V. \& Tatomir, I. (2017). The role of mass open online courses in the modern "educational landscape". Ukraine economy, 12 (673), 86-98.

10.Romanovsky, O.G., Kvasnyk, O.V., Moroz, V.M., Pidbutska, N.V., Reznik, S.M., Cherkashin, A.I. \& Shapolova, V.V. (2019). Factors of development and directions of improvement of the distance form of 
education in the system of higher education of Ukraine. Information technologies and teaching aids, 6, 2042.

11.Khalikov, A.A. \& Musamedova, K.A. (2013). Analysis of distance learning methods and implementation of distance learning in educational institutions. Rostov $\mathrm{n} / \mathrm{D}$.

12.Shabanov, G.A. (2017). Pedagogical problems of quality assurance of online education. Higher education today, 5, 11-15.

13.Anderson, T. (2011). The theory and practice of online learning. 2nd Edition. Edmonton, AB: AU Press. 14.Danver, S.L. (2016). The SAGE encyclopedia of online education. Thousand Oaks, California: SAGE Publications Inc.

15.Horn, M.B. \& Staker, H. (2014). Blended: Using disruptive innovation to improve schools. San Francisco, CA: John Wiley \& Sons.

Received: November 29, 2020 Approved: December 17, 2020 